地域完結型急性期病院における大腿骨近位部骨折患者の総在院日数に 影響を及ぼす因子の検討

一電子化地域連携クリティカルパスを用いた過去10年間の調査一

\title{
Factors affecting the total length of stay in community-contained acute care hospitals among patients with proximal hip fractures -Investigation with the liaison critical pathway of the past 10 years-
}

\author{
吉永 龍史 ${ }^{1}$, 林田 祐醍 ${ }^{1}$, 田所 広太 ${ }^{1)}$, 藤原 崇光 ${ }^{1}$ \\ 宮川 恵輔1), 渡邊 靖晃 ${ }^{1)}$, 高野 雅弘 ${ }^{1)}$, 前田 智 ${ }^{2}$
}

Ryuji Yoshinaga, MS, $\mathrm{PT}^{1}$, Yudai Hayashida, $\mathrm{PT}^{1}$, Kota Tadokoro, $\mathrm{PT}^{1}$, Takamitsu Fujiwara, $\mathrm{PT}^{1)}$ Keisuke Miyagawa $\mathrm{PT}^{1)}$, Yasuaki Watanabe, $\mathrm{PT}^{1)}$, Masahiro Takano, $\mathrm{PT}^{1 /}$, Maeda Satoshi, $\mathrm{MD}^{2)}$

\begin{abstract}
要旨：〔目的〕大腿骨近位部骨折患者の総在院日数に影響を及ぼす要因を地域完結型急性 期病院の電子化された地域連携クリティカルパス項目から検討した。〔対象〕大腿骨近位 部骨折332名とした。〔方法〕急性期と回復期病院の日数を合計した総在院日数を, 中央值 を境界として短期群と長期群の 2 群に分類し，急性期から回復期病院へ転院する際の急性 期パス項目から影響要因を後方視的に調査した。〔結果〕ロジスティック回帰分析の結果, 年齢, 認知症および術式など既知の交絡因子で調整した影響要因は, 杖歩行開始日数であっ た。〔結語〕杖歩行開始日数は, 総在院日数の影響要因として臨床的に有用である可能性 がある。

キーワード：大腿骨近位部骨折，地域連携クリティカルパス，在院日数

Abstract: [Purpose] The purpose of the present study was to analyze factors for community-contained acute care hospitals that affect the total length of stay in acute care and rehabilitation hospitals among patients with proximal hip fractures. [Patients] Three hundred and thirty two patients undergoing surgery for proximal hip fractures were recruited. [Methods] Using the median value of the total length of stay, we classified the patients into two groups: a short-term group and long-term group. We retrospectively analyzed factors at the time of transfer from acute care hospitals to rehabilitation hospitals. [Results] A logistic regression analysis identified the starting date for cane walking as an independent factor. [Conclusion] A late starting date for cane walking may be clinically beneficial for long-term hospital stays.
\end{abstract}

Key words: hip fracture, liaison critical pathway, length of stay

\footnotetext{
受付日：2016年 8 月15日, 採択日：2016年10月31日

国立病院機構熊本医療センター リハビリテーション科：テ860-0008 熊本市中央区二の丸 1 - 5 電話番号：096-353-6501 FAX 番号：096-325-2519 E-mail : snowboard_atp@yahoo.co.jp Department of Rehabilitation, National Hospital Organization Kumamoto Medical Center 1-5 Ninomaru, Chuo-ku, Kumamoto-city, Kumamoto 860-0008, Japan. TEL:+81-96-353-6501 FAX:+81-96-325-2519 E-mail: snowboard_atp@yahoo.co.jp 


\section{I 、はじめに}

大腿骨頚部骨折および大腿骨転子部骨折である大腿 骨近位部骨折は, 本邦の超高齢社会に伴い年々増加し ている ${ }^{1)}$ 。医療機関の機能分化とともに病院・施設完 結型から地域完結型医療へと変遷する現在の地域医療 は，地域連携クリティカルパス（以下，連携パス）が 必要である。2003年10月に熊本市では, 地域の医療連 携を図るため大腿骨頚部骨折治療ネットワークを組織 し，継ぎ目のないケアを提供するという意味でシーム レスケア研究会が発足した。当初 6 施設で発足した本 研究会では，現在，50施設以上の急性期および回復期 病院, 診療所が参加している。連携パスは, 急性期か ら回復期病院を退院するまで 2 施設間の入力項目が設 けられた治療全体の流れを示すオーバービューパスで ある。また，この特徴は，多施設間で情報が共有でき るようデータベースとして電子化された連携パス（以 下，IT連携パス）であり，会員制ホームページによっ て入力および閲覧が PC から可能となっている。

連携パスによる効果検証は多く報告されている。先 行研究によると, 大腿骨近位部骨折を対象とした術後 のリハビリテーションを遷延させる要因は, 年齢 ${ }^{2}$, 受傷前歩行能力 ${ }^{3)}$, 認知症 ${ }^{4,5)}$, 介護者の有無 ${ }^{6)}$, 手術 待機日数 ${ }^{7)}$, 荷重制限 ${ }^{8)}$, 痛み ${ }^{9)}$, 術後合併症 ${ }^{10)}$ なとで ある。地域完結型医療の急性期病院の場合, 術後は回 復期病院などの地域の後方施設へ早期に転院となる。 転院後は前述した要因を含め, 患者および社会的要因 などさまざまな影響を受けて回復期病院から退院する ことになる。特に, 在院日数に関しては, 連携パス導 入により短縮する効果が高い ${ }^{11)}$ との報告が散見される が, 施設完結型医療を対象として行っている先行研究 がほとんどである。在院日数が短い地域完結型医療の 急性期病院の立場からは, 症例の在院日数が今後どの ようになるのかを回復期病院へ転院する早期の時点で 予測することが求められている。急性期と回復期病院 を合計した総在院日数の早期予測要因が明らかとなれ ば, 回復期病院では転院時点より在院日数短縮に向け た対応方法を検討することが期待できる。一方，これ までの先行研究では, 年齢 ${ }^{2}$ や認知症 ${ }^{4,5)}$ などといった 在院日数の長期化に影響する交絡因子の調整を行った 研究は少ない。

本研究目的は, 地域完結型急性期病院の大腿骨近位 部骨折患者における術後の総在院日数に影響を及ぼす 要因をIT連携パス項目から検証した。

\section{II. 対象と方法}

\section{1. 対 象}

対象は，平成16年 4 月から平成26年 7 月までに当院 から熊本大腿骨頚部骨折シームレス研究会の連携施設 に転院した875例より，術後の総在院日数について未 入力 315 例を除外した560例であった。この内，除外基 準は人工骨頭置換術後ステム周囲骨折 1 例，交通事故 3 例，偽関節 1 例，大腿骨転子下と骨幹部骨折の複合 骨折 1 例，死亡転帰 12 例，受傷前歩行能力が車椅子の 患者26例および長谷川式簡易知能評価スケール（以下， HDS-R）未入力 185 例とし，最終的な解析対象は332例 であった（図 1 ）。基本属性は，年齢84.1 1 7.9歳，男 性が55例，女性が277例，診断名が大腿骨頝部骨折170 例，転子部骨折153例，その他 9 例，術式が骨接合術 214 例，人工骨頭置換術118例であった。受傷前歩行能 力は, 独歩 150 名, 杖歩行 90 名, 歩行器歩行・押し車 35 名, 伝い歩き 29 名, 介助歩行 8 名, 不明 4 名および 未入力 16 名であった。対象者の基本情報の詳細は，表 1 に示す。なお, 本研究は国立病院機構熊本医療セン ター倫理委員会の承諾を受けて実施した（受付番号： $650)$ 。

\section{2. 方 法}

方法は,リハビリテーション室内に設置されている 本研究会データベースに登録されたIT連携パスのパ ソコンから急性期病院で入力する以下の項目について 後方視的に調査した。抽出した項目は，患者の基本属 性である年齢, 性別, 診断名, 術式, 受傷前所在, 受 傷前歩行能力について，患者・環境要因である認知症, 麻痺の有無，荷重制限，痛み，意欲，問題行動，受傷 から入院までの日数, 手術待機日数, 急性期病院在院 日数, 回復期病院在院日数について, 運動機能要因で

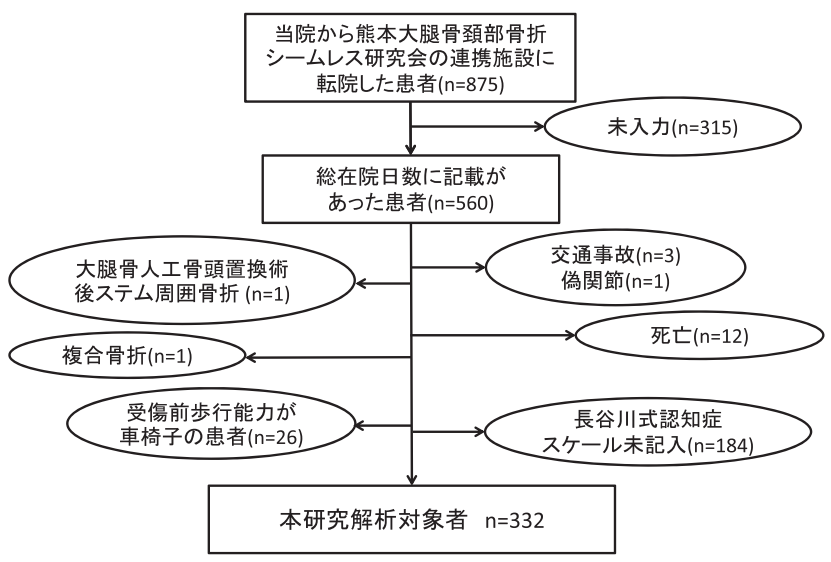

図 1 解析対象者のフローチャート 
ある股関節屈曲および外転の関節可動域，大腿四頭筋 と中殿筋の徒手筋力検查 (以下, MMT), 荷重制限, 退院後所在について, 術後リハビリテーション要因 (以 下，術後リ八要因）である車椅子座位，平行棒内歩行， 歩行器歩行および杖歩行開始日数とした。これらすべ ての量的およびカテゴリーデータは, 患者担当の理学 療法士が急性期病院では患者の転院時, 回復期病院で は患者の退院までに入力および選択することになって いる。認知症の有無は, HDS-R で20点以下を認知症 あり，21点以上を認知症なしと判断した。術後の総在 院日数は, 急性期と回復期病院の在院日数を合計した。 その後, 総在院日数は, 中央值で短期群と長期群の 2 群に分類した。

統計処理は，まず，すべてのデータは KolmogorovSmirnov 検定によりデータの正規性を確認した。基本 属性, 患者・環境要因, 運動機能要因および術後リ八
要因の各項目に関しては，2 変量解析である Fisher の正確確率検定, および対応のないt検定, MannWhitneyの U 検定を用い 2 群間での比率の差あるい は差の有無を確認した。その後, 総在院日数に影響を 及ぼす急性期病院の予測要因を検討するため, 総在院 日数の短期群と長期群の 2 群を従属変数, それぞれの 各項目を独立変数として AIC 基準のステップワイズ 法によるロジスティック回帰分析を行った。この分析 に投入する独立変数は, Hosmer \& Lemeshow の基準 に従い，前述した 2 群間の 2 変量解析にて $\mathrm{p}$ 值が 0.05 未満となる変数とした。さらに独立変数間での多重共 線性の有無を事前の相関関係により評価し，相関係数 が0. 8以上を示す組み合わせの場合は，どちらかの変 数を除外した。また，独立変数の交絡因子の影響を調 整するため, 年齢, 性別, 診断名, 術式, 認知症, 手 術待機日数, 術後合併症, 荷重制限および受傷から入

表 1 対象者の基本情報 $(\mathrm{n}=332)$

\begin{tabular}{|c|c|c|c|}
\hline \multirow[t]{8}{*}{ 基本属性 } & 性別（例） & 男/女 & $55 / 277$ \\
\hline & 年齢（歳） & & $84.1 \pm 7.9$ \\
\hline & 認知症（例） & 無/有 & $133 / 199$ \\
\hline & 受傷前所在（例） & 自宅/施設/病院/不明 & $259 / 50 / 14 / 9$ \\
\hline & 受傷前歩行能力（例） & 独歩/杖/押し車/歩行器/伝い歩き/介助歩行/不明/未入力 & $150 / 90 / 1 / 34 / 29 / 8 / 4 / 16$ \\
\hline & 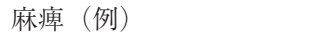 & 無 $/$ 有 & $310 / 22$ \\
\hline & 問題行動（例） & 無/あまりない/どちらともいえない/有 & $259 / 21 / 1 / 51$ \\
\hline & リハビリ意欲（例） & 有/どちらともいえない/あまりない/無/不明 & $228 / 38 / 45 / 20 / 1$ \\
\hline 診断名（例） & & 大腿骨頚部骨折/転子部/その他 & $170 / 153 / 9$ \\
\hline \multirow[t]{2}{*}{ 術式（例） } & & 骨接合術/人工骨頭置換術 & $214 / 118$ \\
\hline & & 右/左 & $147 / 185$ \\
\hline 受傷から入院まで日数 & & & $0(0-1)$ \\
\hline 手術待機日数 & & & $6(4-8)$ \\
\hline \multirow[t]{3}{*}{ 術後要因 } & 術後合併症（例） & 無/有/不明 & $107 / 15 / 210$ \\
\hline & 荷重制限（例） & 無/有 & $317 / 15$ \\
\hline & 転院時疼痛対策（例） & 無/坐薬/内服薬/その他/不明 & $79 / 190 / 20 / 2 / 41$ \\
\hline \multirow[t]{4}{*}{ 術後リハビリ開始日数 } & 車椅子座位（日） & & $1(1-2)$ \\
\hline & 平行棒内歩行（日） & & $4(2-6)$ \\
\hline & 歩行器歩行（日） & & $7(5-18)$ \\
\hline & 杖歩行（日） & & $21.5(10-39.5)$ \\
\hline \multirow[t]{3}{*}{ 転院時運動機能 } & 大腿四頭筋 MMT & & $3(3-3)$ \\
\hline & 中殿筋 MMT & & $2(2-3)$ \\
\hline & 痛み（例） & 有/あまりない/無 & $232 / 92 / 8$ \\
\hline \multirow[t]{2}{*}{ 関節可動域 } & 股関節外転（） & & $20(20-30)$ \\
\hline & 股関節屈曲 $\left({ }^{\circ} ）\right.$ & & $90(90-95)$ \\
\hline \multirow[t]{4}{*}{ 転帰（例） } & & 治癒/軽快/寛解/不変/増悪/その他/不明 & $106 / 61 / 4 / 7 / 10 / 10 / 134$ \\
\hline & 最終自立度（例） & 自立/監視/人的介助/全介助/未入力 & $169 / 50 / 43 / 33 / 37$ \\
\hline & 最終歩行獲得レベル(例) & 独歩/杖/伝え歩き/押し車/歩行器歩行/車椅子/不能/不明 & $59 / 81 / 19 / 3 / 93 / 45 / 3 / 20$ \\
\hline & 退院後所在（例） & 自宅/施設/病院/未入力 & $176 / 71 / 32 / 53$ \\
\hline \multirow[t]{3}{*}{ 術後在院日数（日） } & 地域完結型急性期病院 & & $12(9-14)$ \\
\hline & 転院先回復期病院など & & $82.5(59-95)$ \\
\hline & 総在院日数 & & $94(71.75-108)$ \\
\hline
\end{tabular}


院までの日数については強制投入した。次に, 抽出さ れた独立変数について, 受信者動作特性 (Receiver Operating Characteristic; ROC) 曲線より cut off 值およ び判別制度（感度, 特異度, 曲線下面積)について検 討した。cut off 值の判定基準は, 閯值以上を陽性と し，感度と特異度の和が最大となる点に設定した。な お，いずれも有意水準は，両側 $1 \%$ 未満とした。すべ ての統計解析には, EZR on R commander (ver. 1.27) を使用した。

\section{III. 結 果}

総在院日数の短期群（ $\mathrm{n}=163 ）$ および長期群（ $\mathrm{n}=$ 169）の中央值（四分位範囲）は，それぞれ71（55.5 -84.5）日，108（101-117）日であった。その他の 2 群間の比較は, 表 2 に示す。ロジスティック回帰分 析の結果, 総在院日数に影響を与える要因は, 術後か
ら杖歩行開始日数 $(\mathrm{p}<0.05)$ であり, オッズ比が 1.06 倍（95\%信頼区間1.00-1.13）であった（表 3)。ま た，杖歩行開始日数に関して ROC 分析を行った結果， cut off 值は29日, 感度76.3\%, 特異度 $62.0 \%$, 曲線 下面積0.7（95\%信頼区間0.62-0.78）であった（図 2 )。

\section{IV. 考 察}

本研究結果より, 大腿骨近位部骨折患者において, 年齢, 認知症および術式などの影響を考慮した総在院 日数は, 術後からの杖歩行開始日数が影響要因として 抽出された。多変量解析を実施した先行研究によると, 本邦の大腿骨近位部骨折患者の在院日数が長期化する 要因は, 感染性合併症 ${ }^{12)}$, 民間病院への入院 ${ }^{12}$, 入院 から手術までの期間が 3 日超 ${ }^{12}$, 手術からリハビリ テーション開始までの期間が 1 日超 ${ }^{12)}$ ，骨折型13)，認

表 2 急性期と回復期病院を合計した総在院日数を中央值で分類した 2 群間の急性期パス項目の比較

\begin{tabular}{|c|c|c|c|c|c|}
\hline & & & 短期群 $(n=163)$ & 長期群（n=169） & $\mathrm{p}$ 值 \\
\hline \multirow[t]{8}{*}{ 基本属性 } & 性別（例） & 男/女 & $25 / 138$ & $30 / 139$ & 0.66 \\
\hline & 年齢（歳） & & $83.9 \pm 7.8$ & $84.3 \pm 8.0$ & 0.6 \\
\hline & 認知症（例） & 無/有 & $78 / 85$ & $55 / 114$ & $<0.001$ \\
\hline & 受傷前所在（例） & 自宅/施設/病院/不明 & $123 / 31 / 5 / 4$ & $136 / 19 / 9 / 5$ & 0.19 \\
\hline & 受傷前歩行能力（例） & 独歩/杖/押し車/歩行器歩行/伝い歩き/介助/不明 & $83 / 43 / 0 / 12 / 9 / 6 / 10$ & $67 / 47 / 1 / 22 / 20 / 2 / 10$ & 0.05 \\
\hline & 麻痺（例） & 無/有 & $155 / 8$ & $155 / 14$ & 0.27 \\
\hline & 問題行動（例） & 無/あまりない/どちらともいえない/有 & $124 / 11 / 1 / 27$ & $135 / 10 / 0 / 24$ & 0.74 \\
\hline & リハビリ意欲 (例) & 有/どちらともいえない/あまりない/無 & $115 / 19 / 18 / 11$ & $113 / 19 / 27 / 9$ & 0.59 \\
\hline 診断名（例） & & 大腿骨䅡部骨折/転子部骨折/その他 & $96 / 64 / 3$ & $74 / 89 / 6$ & $<0.05$ \\
\hline \multirow[t]{2}{*}{ 術式 (例) } & & 骨接合術/人工骨頭置換術 & $93 / 70$ & $121 / 48$ & $<0.01$ \\
\hline & & 右/左 & $78 / 85$ & $69 / 100$ & 0.19 \\
\hline 受傷から入院まで日数 & & & $0(0-0)$ & $0(0-1)$ & 0.68 \\
\hline 手術待機日数 & & & $5(4-7)$ & $5(3-7)$ & 0.73 \\
\hline \multirow[t]{3}{*}{ 術後要因 } & 術後合併症（例） & 無/有/不明 & $59 / 6 / 98$ & $48 / 9 / 112$ & 0.28 \\
\hline & 荷重制限（例） & 無/有 & $157 / 6$ & $160 / 9$ & 0.6 \\
\hline & 転院時疼痛対策（例） & 無/内服薬/坐薬/その他/不明 & $42 / 10 / 91 / 1 / 19$ & $37 / 10 / 99 / 1 / 22$ & 0.93 \\
\hline \multirow[t]{4}{*}{ 術後リハビリ開始日数 } & 車椅子座位（日） & & $1(1-1)$ & $1(1-2)$ & 0.21 \\
\hline & 平行棒内歩行（日） & & $3(2-5)$ & $4(2-7)$ & $<0.05$ \\
\hline & 歩行器歩行（日） & & $6(4-11)$ & $10(6-28)$ & $<0.001$ \\
\hline & 杖歩行（日） & & $16(8-28)$ & $34(13.5-53.5)$ & $<0.001$ \\
\hline \multirow[t]{3}{*}{ 転院時運動機能 } & 大腿四頭筋 MMT & & $3(3-3)$ & $3(3-3)$ & 0.33 \\
\hline & 中殿筋 MMT & & $2(2-3)$ & $2(2-2)$ & $<0.05$ \\
\hline & 痛み (例) & 有/あまりない/無 & $110 / 47 / 6$ & $122 / 45 / 2$ & 0.28 \\
\hline \multirow[t]{2}{*}{ 関節可動域 } & 股関節外転 $\left({ }^{\circ}\right)$ & & $20(20-30)$ & $20(20-30)$ & 0.88 \\
\hline & 股関節屈曲（） & & $90(90-95)$ & $90(90-95)$ & $<0.05$ \\
\hline 術後在院日数（日） & 地域完結型急性期病院 & & $11(9-14)$ & $12(10-14)$ & 0.26 \\
\hline
\end{tabular}


表 3 中央值で分類した総在院日数の 2 群を従属変数としたロジスティック回㷌分析

\begin{tabular}{|c|c|c|c|c|}
\hline & \multicolumn{4}{|c|}{ 95\%信頼区間 } \\
\hline & & 上限 & 下限 & p 怛 \\
\hline 年齢 & 0.93 & 0.85 & 1.02 & 0.14 \\
\hline 性別 [男] & 0.18 & 0.02 & 1.64 & 0.13 \\
\hline 認知症 [有 $]$ & 4.91 & 0.85 & 28.5 & 0.08 \\
\hline 診断名 [大腿骨頚部骨折] & 2.92 & 0.05 & 182 & 0.61 \\
\hline [大腿骨転子部骨折] & 2. 67 & 0.06 & 112 & 0.61 \\
\hline 術式［人工骨頭置換術］ & 0.44 & 0.04 & 4.7 & 0.50 \\
\hline 受傷から入院までの日数 & 0.98 & 0.72 & 1.33 & 0.89 \\
\hline 受傷から手術までの日数 & 1.02 & 0.80 & 1.3 & 0.87 \\
\hline 術後合併症の有無 $[$ 有 $]$ & 4. 21 & 0.33 & 53.8 & 0.27 \\
\hline 荷重制限 [有］ & 推定不能 & 0.00 & 推定不能 & 1.00 \\
\hline 杖歩行開始日数 & 1.06 & 1.00 & 1.13 & $<0.05$ \\
\hline
\end{tabular}

知症 ${ }^{13)}$, 受傷から離床までの期間 ${ }^{13)}$ と報告されている。 しかし, これらの先行研究は, いずれも転院した症例 を除外した病院・施設完結型病院の対象者であった。 今回, 先行研究と比較して異なる結果になった理由は, 対象者の属性の違いが挙げられる。我々が対象とした 症例は急性期病院から回復期病院などへ転院した症例 であり，現在の地域医療における地域完結型病院の患 者層であった。さらに本研究の検討は, 急性期から回 復期病院へ転院する時点の早期予測要因であることが, 先行研究との相違点であり, 在院日数を長期化する要 因が異なったと考えられる。本研究結果は, オッズ比 は低いものの, 先行研究と同様に術後のリハビリテー ションの進め方が非常に重要であることが示唆された。 しかし, 本研究の杖歩行開始日数の cut off 值は, 29 日であったため, 杖歩行練習を開始する前に既に急性 期病院を転院している可能性が高い。本研究の急性期 病院の在院日数は中央值で 12 日であることから, 急性 期病院から転院時に在院日数を予測できるのは, 入院 期間が長くなった一部の症例に限られてしまう。また, 本研究結果は, 杖歩行が可能であると予測される症例 に適応できることになる。急性期病院転院時から早期 に予測できるとは言い難いが, 杖歩行練習が遅延しそ うな症例に対しては, 転院先に情報提供を実施するこ とで, 在院日数短縮に向けた対応方法を検討できると 考えられる。

今回の成績は, 急性期病院転院時の年齢, 性別, 診 断名, 術式, 認知症, 手術待機日数, 術後合併症, 荷 重制限および受傷から入院までの日数を調整した結果 であるため, 予測要因として用いやすいという臨床的 意義がある。特に, 年齢と認知症に関しては, 歩行獲

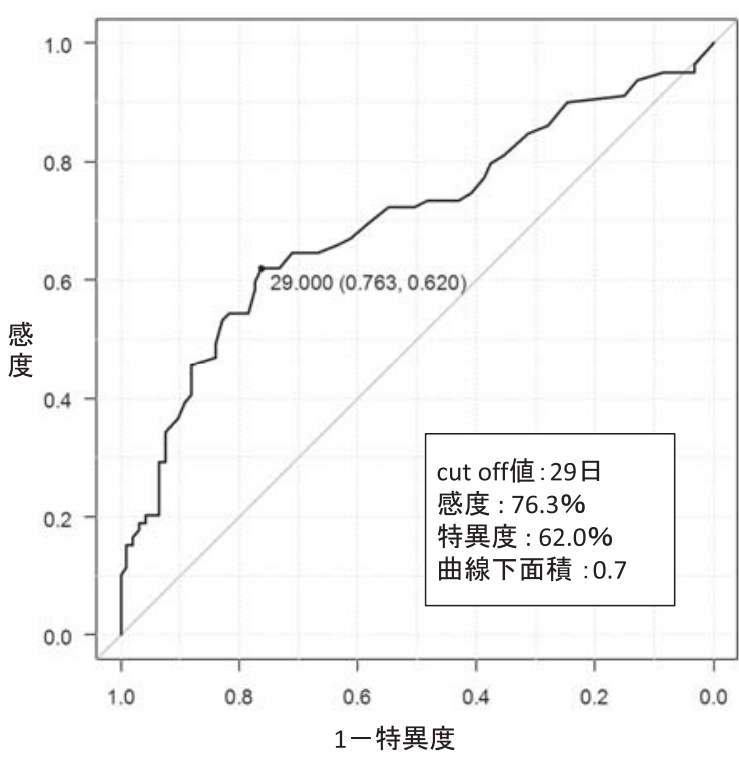

図 2 術後から杖歩行開始日数の ROC 曲線

得の阻害因子である多くの報告 ${ }^{14-16)}$ があり, 術後の総 在院日数について子測したい場合は, 地域完結型急性 期病院の一つの基礎資料となりうる。

本研究には三つの限界がある。一つ目は, 総在院日 数の短期群と長期群の 2 群の分類が不明瞭であったこ とである。現状, IT 連携パスの術後在院日数は, 骨 接合術が12週（84日），人工骨頭置換が10週（70日） と術式別で設定 ${ }^{17)}$ されている。今後は, 術式別に在院 日数の短期群および長期群を明確に分類して検討して いく必要がある。二つ目は，当院に入院したすべての 患者が本研究会の連携施設に転院していないため, 連 携施設以外の対象者がどのような経過を追ったのか不 明であり，この点にバイアスが存在する。三つ目は， IT 連携パスからの後方的調査であったため, 転院先 のパス項目に未入力があり情報収集できなかった症例 が存在した。廣瀬らはIT連携パスにおいてデータの 入力状況が低下傾向で, 特に症例数の少ない施設の入 力率が低かった ${ }^{18)}$ と述べており, 今後, これらの点を 踏まえて地域と医療連携を四らなければならない。

本研究では，大腿骨近位部骨折患者において，急性 期病院転院時の年齢, 性別, 診断名, 術式, 認知症, 手術待機日数, 術後合併症, 荷重制限および受傷から 入院までの日数で調整した総在院日数は, 術後から杖 歩行開始日数が影響要因であった。杖歩行開始日数は, 急性期と回復期病院の在院日数を合わせた総在院日数 の予測要因として臨床的に有用である可能性がある。 今後は, 病棟での歩行器歩行あるいは杖歩行がいつ自 立できたかといった自立日数の影響も検討したい。 


\section{引用文献}

1) Orimo $H$, Yaegashi $Y$, Onoda $T$, et al.: Hip fracture incidence in Japan: estimates of new patients in 2007 and 20year trends. Arch Osteoporos, 2009, 4: 71-77.

2) Vochteloo AJ, Borger van der Burg BL, Tuinebreijer WE, et al: Do clinical characteristics and outcome in nonagenarians with a hip fracture differ from younger patients? Geriatr Gerontol Int, 2013, 13(1): 190-197.

3）長嶋秀明, 太田壮一, 杉本正幸 - 他：当院における大腿骨 頸部骨折の現状．中部整災誌，2010，53(3)：615-616.

4) 田中一成, 高橋紀代 : 認知症は大腿骨近位部骨折回復期リ 八の阻害因子か？中部整災誌，2012，55(1)：59-60.

5) 渡辺充伸：人工大腿骨頭置換術後の在院日数と認知症と疼 痛の関係。骨折, 2012, 34(1) : 105-108.

6）久保田敬也, 飛田格子：大腿骨頸部骨折の術後の経過に及 ぼす因子の検討。東日整災外会誌，2009，21(1)：81-84.

7）原 良太，服部耕治，河原郁生・他：高齢者大腿骨近位部 骨折に扮ける早期退院の現状 - 2005年 1 月～2006年 6 月ま でのカルテ調査の結果報告一。骨折, 2009, 31(1)：22-24.

8）小川優美, 佐藤真由美, 神川康也：受傷前の移動能力・認 知機能により層別化した大腿骨頸部骨折地域連携クリティ カルパスの検討. 医療マネジメント会誌, 2012, 13(1)： $7-10$.

9）川端悠士，澄川泰弘，林 真美 - 他：大腿骨近位部骨折術 後例における杖歩行の可否 ·歩行速度を決定する可変的要 因の検討. 理学療法学, 2014, 41(6) : 347-354.

10）廣瀬 隼, 野村一俊：地域医療連携に打ける大腿骨近位部 骨折に対するIT 連携パスのバリアンス評価。骨折, 2007, 29(4) : 757-760.

11) Koval KJ, Chen AL, Aharonoff GB, et al.:Clinical pathway for hip fractures in the elderly: the Hospital for Joint Diseases experience. Clin Orthop Relat Res, 2004, 425: 72-81.

12) Takahashi C, Fushimi K, Matsuda S. : Factors associated with a protracted hospital stay after hip fracture surgery in Japan. Geriatr Gerontol Int, 2011, 11(4): 474-481.

13）鈴木秀和, 山本謙吾 : 高齢者大腿骨頸部骨折の入院長期化 に関与する因子. 日本関節病学会誌, 2009, 28(1)：109113.

14）今嶋由香理, 西川梅雄, 鈴木玄一郎 - 他 : 大腿骨転子部骨 折患者の術後歩行能力に痴呆が及ぼす影響. 中四整外会誌, 2005, $17: 81-84$.

15）河本旭哉, 棚瀬嘉宏, 渡辺康司 - 他：大腿骨転子部骨折に 対する Gamma nail 法の治療成績 術後歩行能力の低下に 影響する因子の分析. 整形外科, 2002，53：395-398.

16) Holt EM, Evans RA, Hindley CJ, et al.: 1000 femoral neck fractures:the effect of pre-injury mobility and surgical experience on outcome. Injury, 1994, 25: 91-95.

17）前田 智：熊本市における大腿骨近位部骨折地域連携クリ ティカルパスの現状と課題. 医療, 2014，68(9)：445-447.

18）廣瀬 隼, 瀬形建喜, 堤康次郎：大腿骨近位部骨折に対す る地域連携パスの運用効果と利用状況. 骨折, 2011, 33 (1) : 167-169. 